\title{
Mineral Resources of the Mount Limbo Wilderness Study Area, Pershing County, Nevada
}

\section{U.S. GEOLOGICAL SURVEY BULLETIN 1726-A}

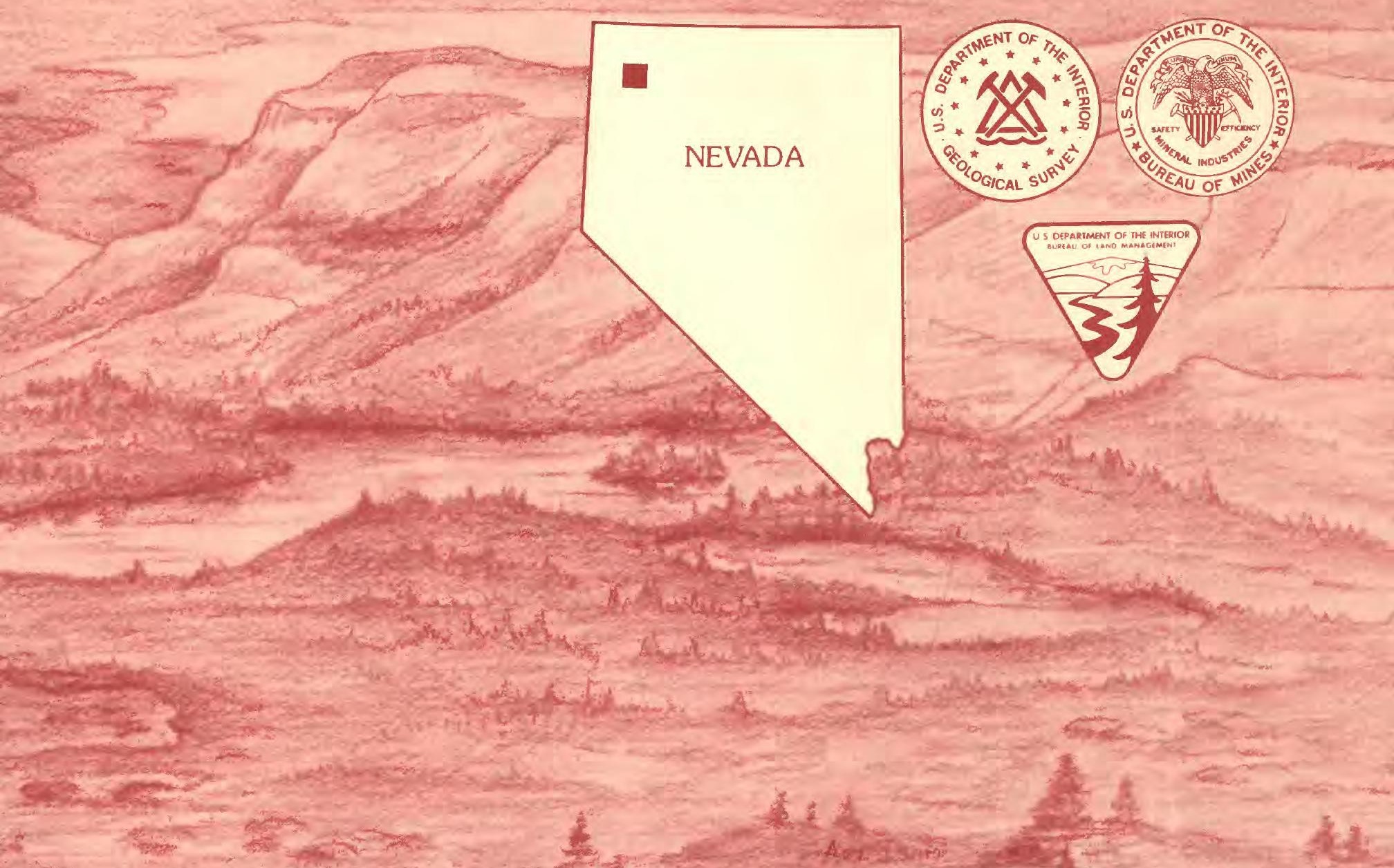





\title{
Mineral Resources of the Mount Limbo Wilderness Study Area, Pershing County, Nevada
}

\author{
BY WILLIAM J. KEITH, ROBERT L. TURNER, \\ and DONALD PLOUFF \\ U.S. Geological Survey
}

CLAYTON M. RUMSEY U.S. Bureau of Mines

U.S. GEOLOGICAL SURVEY BULLETIN 1726-A MINERAL RESOURCES OF WILDERNESS STUDY AREAS: HUMBOLDT AND PERSHING COUNTIES, NEVADA 


\title{
DEPARTMENT OF THE INTERIOR \\ DONALD PAUL HODEL, Secretary
}

\author{
U.S. GEOLOGICAL SURVEY
}

Dallas L. Peck, Director

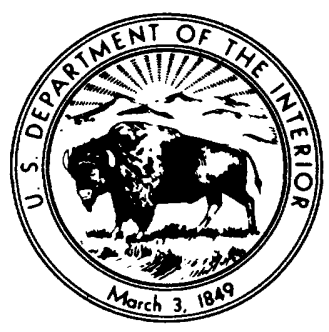

For sale by the

Books and Open-File Reports Section

U.S. Geological Survey

Federal Center, Box 25425

Denver, CO 80225

Library of Congress Cataloging-in-Publication Data

Mineral resources of the Mount Limbo Wilderness Study Area, Pershing County, Nevada.

U.S. Geological Survey Bulletin 1726-A

Bibliography: p. 4

Supt. of Docs. No.: I 19.3:1726-A

1. Mines and mineral resources-Nevada-Mount Limbo

Wilderness. 2. Geology-Nevada-Mount Limbo

Wilderness. 3. Mount Limbo Wilderness (Nev.) I. Keith,

William J., 1933-

. II. Series.

QE75.B9 No. 1726-A $\quad 557.3$ s $\quad 86-600348$

[TN24.N3]

[553'.09793'53] 


\section{STUDIES RELATED TO WILDERNESS}

\section{Bureau of Land Management Wilderness Study Area}

The Federal Land Policy and Management Act (Public Law 94-579, October 21, 1976) requires the U.S. Geological Survey and the U.S. Bureau of Mines to conduct mineral surveys of certain areas to determine the mineral values, if any, that may be present. Results must be made available to the public and be submitted to the President and the Congress. This report presents the results of a mineral survey of part of the Mount Limbo Wilderness Study Area (NV-020-201). Pershing County. Nevada. 


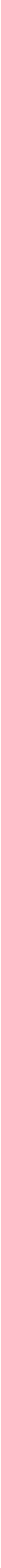




\section{CONTENTS}

\section{Summary}

Abstract A1

Character and setting 1

Identified resources 1

Mineral resource potential 1

Introduction $\mathbf{3}$

Area description $\mathbf{3}$

Previous and present investigations

Acknow ledgments $\mathbf{3}$

Appraisal of identified resources $\mathbf{3}$

Methods $\mathbf{3}$

Mining history $\mathbf{3}$

Sites studied 6

Conclusions 6

Assessment of potential for undiscovered resources

Geological studies 6

Geochemical studies 6

Geophysical studies 7

Mineral and energy resources 7

References cited 7

Appendix 1. Definition of levels of mineral resource potential and certainty of assessment 10 Geologic time chart 11

\section{Figures}

1. Index map showing the location of the Mount Limbo Wilderness Study Area, Pershing County. Nevada

2. Geologic map of the Mount Limbo Wilderness Study Area showing prospects, mineralized areas. and areas of mineral resource potential 4

3. Major elements of mineral resource potential/certainty classification

10

\section{Tables}

1. Descriptions of prospects and sinter or tufa sites in the Mount Limbo Wilderness Study Area 


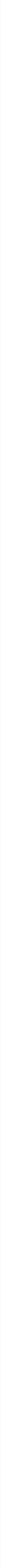




\title{
Mineral Resources of the Mount Limbo Wilderness Study Area, Pershing County, Nevada
}

\author{
By William J. Keith, Robert L. Turner, and Donald Plouff \\ U.S. Geological Survey
}

Clayton M. Rumsey

U.S. Bureau of Mines

\section{SUMMARY}

\section{Abstract}

At the request of the Bureau of Land Management, 12,900 acres of the Mount Limbo Wilderness Study Area (NV-020-201) were studied. In this report, the area studied is referred to as "the wilderness study area," or simply "the study area." The study area is located at the southern end of the Selenite Range in Pershing County, Nev. Geological, geochemical, geophysical, and mineral surveys were conducted by the U.S, Geological Survey and the U.S. Bureau of Mines from 1983 to 1986 to assess the mineral resource potential of the study area. No resources were identified in the area; however, the results of these surveys indicate the existence of a zone with moderate potential for the southern end of the study area. Elsewhere within the study area, the potential for gold and silver resources is low. Potential for geothermal resources is low in the entire study area. The granitic and volcanic rocks found in the study area are unfavorable for the accumulation of oil and gas.

\section{Character and Setting}

The study area is located at the southern end of the Selenite Range, approximately $20 \mathrm{mi}$ southeast of Gerlach, Nev. (fig. 1). The topography is typical of the
Basin and Range geomorphic province, with northsouth trending fault-bounded valleys and ranges. It is an area of high relief, ranging from $4,000 \mathrm{ft}$ at the valley floor to $8.237 \mathrm{ft}$ at the summit of Kumiva Peak. The study area comprises a granodiorite pluton of Cretaceous age (63 to 138 million years before present. or Ma) (see Geologic Time Chart. last page of report) bounded on the east and west by high-angle normal faults. Small felsic to mafic, aplitic to pegmatitic dikes intrude the pluton. Alluviated valleys flank the study area.

\section{Identified Resources}

Four prospects are located in the study area, but it contains no mines or active claims. Past interest centered on locally mineralized quart $z$ veins. but they contained no identified mineral resources. Small tufa (calcareous sinter) deposits in the southwest part of the study area contain low concentrations of gold and silver and may be significant. Stone, sand, and gravel are present in the study area but are distant from anticipated markets.

\section{Mineral Resource Potential}

The southernmost part of the study area has moderate resource potential for gold and silver (fig. 2). Stream-sediment samples from this part of the study area contain anomalous concentrations of a suite of elements (arsenic. antimony, bismuth, cadmium. and 


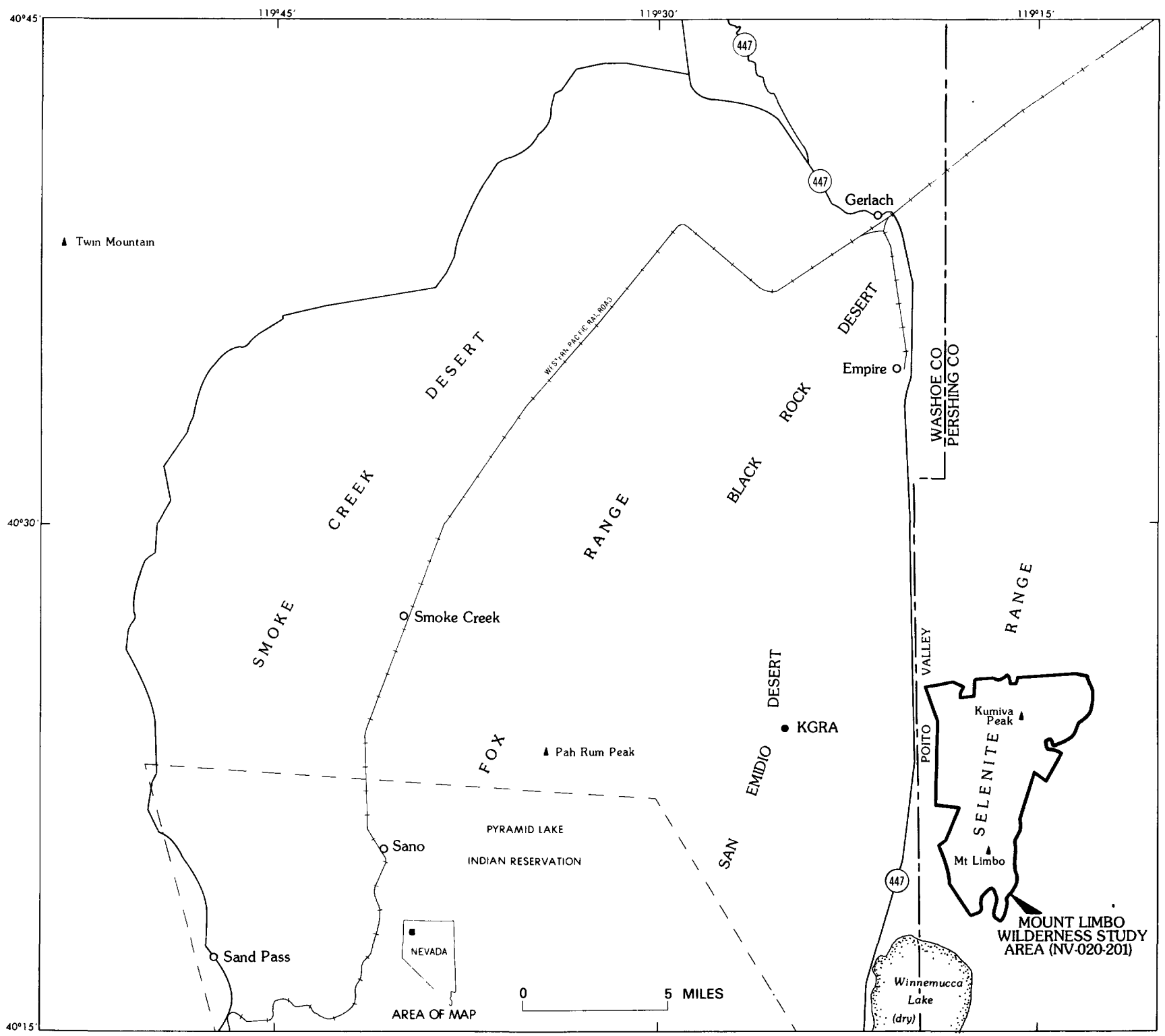

Figure 1. Index map showing the location of the Mount Limbo Wilderness Study Area, Pershing County, Nevada. 
silver) that typically occur in gold and silver vein deposits. The presence of faults and veins in this area also facilitates this type of mineralization. Most of the observed alteration consists of thin (several inches thick) argillic selveges around veins and oxidation halos adjacent to minor faults and fractures.

In the rest of the study area the rarity of veins and absence of extensive alteration indicate low potential for gold and silver resources.

The potential for geothermal resources in the study area is low. although a known geothermal resource area (KGRA), with water temperatures as high as $95^{\circ} \mathrm{C}$. is located in the San Emidio desert (fig. 1. KGRA) 4 mi west of the study area.

The granitic and volcanic rocks found in the study area are not favorable host rocks for the accumulation of hydrocarbons.

\section{INTRODUCTION}

\section{Area Description}

At the request of the Bureau of Land Management, 12.900 acres of the Mount Limbo Wilderness Study Area (NV-020-201) were studied. In this report, the area studied is referred to as "the wilderness study area," or simply "the study area." The study area consists of rugged, sparsely vegetated terrain bordering the northeast edge of Winnemucca Dry Lake in western Pershing County, Nev. (fig. 1). It is located in the southernmost part of the Selenite Range and is flanked by broad ( 2 mi wide on the west, $10 \mathrm{mi}$ wide on the east) alluviated valleys. The area is accessible by gravel roads on all sides, but the interior is accessible only by helicopter. horseback. or on foot. Altitudes range from $4,000 \mathrm{ft}$ at the southern tip of the study area to $8.237 \mathrm{ft}$ at Kumiva Peak near the north end.

\section{Previous and Present Investigations}

A geologic map of the study area prepared by the U.S. Geological Survey in 1984 (fig. 2) at a scale of $1: 62.500$ provided a basis for the interpretation of geochemical. geophysical and mining claim data. Supplemental geologic data for the north end of the study area was taken from a Master's thesis by R.A. Crewdson (1974).

Studies by Smith and others (1971). Johnson (1977), and the U.S. Bureau of Land Management (1983) also provided geologic data for this report.

Geochemical data were obtained from a geochemical-geostatistical study done for the U.S. Bureau of Land Management by Barringer Resources, Inc. (1982) and from analyses of stream-sediment and rock-chip samples collected by the U.S. Geological Survey in 1984 (Day and others. 1986).

Earlier geophysical data, which consisted of a regional gamma-ray survey (Geodata International. Inc., 1978) and aeromagnetic maps (U.S. Geological Survey, 1972). were supplemented in 1984 by a gravity study and a regional gravity compilation conducted by the U.S. Geological Survey (unpub. data).
The U.S. Bureau of Mines studied the known prospects and claims within and adjacent to the study area as a means of developing a model that would predict the grade and tonnage of mineral resources that might occur in the study area (Rumsey, 1986).

\section{Acknowledgments}

The U.S. Geological Survey and the U.S. Bureau of Mines received assistance from the following: V. Dunn. U.S. Bureau of Land Management geologist, provided information on locations of mineralized areas; Helen Thrasher. owner, and Harold Playford. lessee of the Thrasher mine, provided local history and directions; R. Baker. C. Erdman. K. Greene, J. Lewis. and $\mathrm{N}$. Logue assisted in the fieldwork.

\section{APPRAISAL OF IDENTIFIED RESOURCES}

By Clayton M. Rumsey, U.S. Bureau of Mines

\section{Methods}

From 1984 to 1986. the U.S. Bureau of Mines (USBM) conducted a library search and examined U.S. Bureau of Land Management (BLM), USBM, and Pershing County claim and production records in order to determine the level of mining and prospecting activity in the study area. The field study included inspections of all prospects and mineralized localities within the study area. The Thrasher and Stormy Day mines. and three nearby prospects. were examined to determine whether mineralized zones might extend into the study area. In addition. ground and air reconnaissance was done in areas of obvious rock alteration. Sixteen prospects and mineralized sites in and near the study area were examined and 69 samples were collected, including chip samples collected across mineralized zones and grab samples from stockpiles of mineralized rock. All samples were assayed for gold and silver by the combined fire assay-inductively coupled plasma method. The presence and concentration of other elements were determined by atomic-absorption analysis. Selected samples from sites with anomalous radioactivity were analyzed for uranium. Gold and silver concentrations are reported in parts per million $(\mathrm{ppm})$; the content of other elements is reported in ppm or percent. Detection limits were as follows: gold, $0.007 \mathrm{ppm}$; silver, 0.3 ppm; uranium. 0.5 ppm; and lead. $30 \mathrm{ppm}$. Conversion factors are $1 \mathrm{ppm}=0.0292 \mathrm{oz} / \mathrm{ton}$, and $10,000 \mathrm{ppm}=1$ percent.

\section{Mining History}

In 1941 tungsten was discovered in the southern part of the Hooker mining district. which extends to within 1 mile of the north end of the study area. Between 1944 and 1957, the Stormy Day mine produced 19.523 tons of ore containing 1.66 percent tungsten trioxide. The neighboring Thrasher mine produced an unknown amount of tungsten ore (Johnson, 


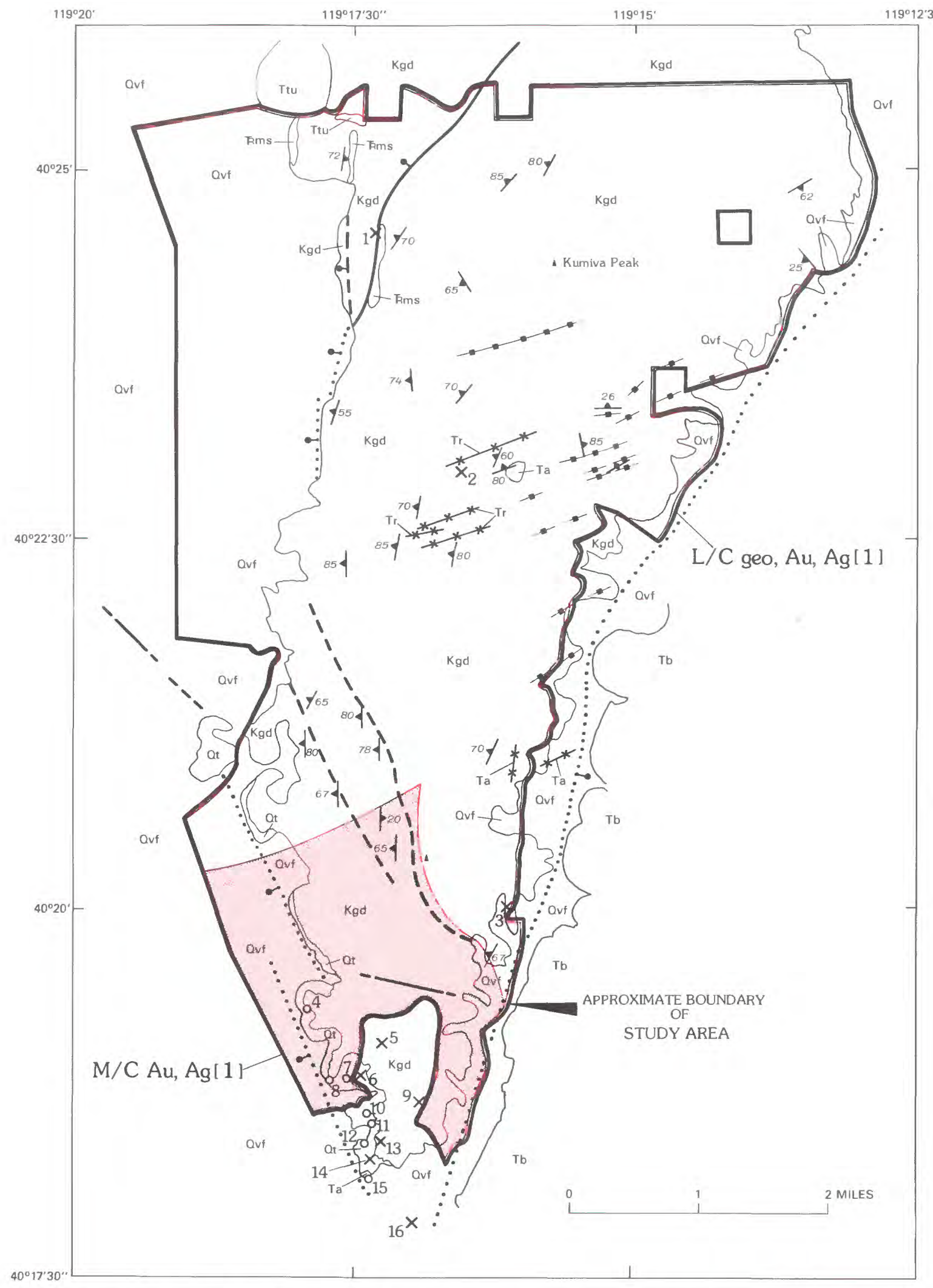

Figure 2. Geologic map of the Mount Limbo Wilderness Study Area showing prospects, mineralized areas, and areas of mineral resource potential. 
AREA WITH MODERATE MINERAL RESOURCE POTENTIAL-Certainty level C (M/C) See Appendix 1 and figure 3 for definition of mineral resource potential and certainty of assessment

AREA WITH LOW MINERAL AND GEOTHERMAL RESOURCE POTENTIAL-Certainty level $\mathrm{C}(\mathrm{L} / \mathrm{C})$

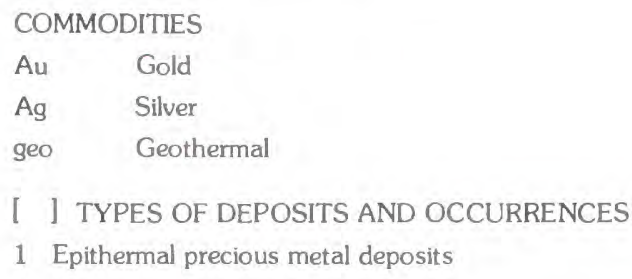

${ }_{11}$ SINTER OR TUFA DEPOSITS SAMPLED-Number refers to table 1

Figure 2. Continued. 
1977. p. 58). Both mines are now inactive. There is no record of mining or production within the study area, and the study area contained no active claims at the time of the study (1984).

\section{Sites Studied}

The 16 prospects and mineralized sites examined (fig. 2) consist of calcareous sinter or tufa deposits and quartz veins in granodiorite (table 1). Quart $z$ veins at prospects in the study area are small and have low mineral concentrations. Although a relatively high concentration of silver $(580 \mathrm{ppm})$ was obtained from a sample collected at one prospect (fig. 2. no. 9). silver concentrations in other samples are relatively low. Sinter or tufa deposits near Winnemucca Lake contain low, yet anomalous, concentrations of gold, silver, and uranium (table 1).

\section{Conclusions}

Although precious-metal resources may occur at depth, none were identified at the surface in the study area. Although there are sites of anomalous uranium. the conditions are not favorable for uranium deposits and no resources are indicated.

Tungsten deposits at the Thrasher and Stormy Day mines (fig. 2) do not extend into the study area. Stone, sand, and gravel, although present, are not considered resources because they are too far from anticipated markets.

\section{ASSESSMENT OF POTENTIAL FOR UNDISCOVERED RESOURCES}

By William J. Keith, Robert L. Turner. and Donald Plouff

U.S. Geological Survey

\section{Geological Studies}

The Selenite Range (fig. 1) is a north-trending mountain range in the Basin and Range physiographic province. The wilderness study area, at the southern tip of the range, contains a fault-bounded granodioritic body (fig. 2, unit Kgd) of Cretaceous age (Smith and others, 1971) that was intruded by mafic, felsic, and aplitic to pegmatitic dikes. Much of the faulting in the study area is of the high-angle basin-range type. Alteration consists largely of oxidized fringes on the faults and dikes and argillic fringes on some of the veins.

The granodiorite pluton consists of plagioclase, potassium feldspar, quartz, hornblende, biotite, and sphene, and has a texture that ranges from generally equigranular in the southern part of the study area to porphyritic in the north. A north-trending plane of foliation is less intense to the north. The northern part of the pluton appears to be younger than the southern part, and younger phases of the pluton locally intrude the older. Inclusions, consisting of hornblende, biotite, plagioclase, and quartz, that occur throughout the pluton. probably are segregations in the pluton rather than xenoliths.

Mafic dikes found in the study area have a wide range of compositions and fill joints and faults in the pluton. The smaller dikes (1- to 24-in. wide), containing fine-grained granular hornblende, biotite, plagioclase, and quartz, occur throughout the pluton but are more numerous in the southern part. One dike composed almost entirely of hornblende was observed on the east side of the study area. Andesite dikes (fig. 2. unit $\mathrm{Ta}$ ), ranging from 1 to $15 \mathrm{ft}$ in width. occur sporadically throughout the pluton. These dikes are aphanitic to porphyritic with sparse phenocrysts (xenocrysts?) of plagioclase and (or) hornblende.

Felsic dikes occur throughout the study area as pegmatites of predominantly potassium feldspar and (or) quartz and as aplites. Locally (north-central ridge crest), 1- to 3-ft-wide dikes of aphanitic rhyolite (fig. 2. Tr) trend approximately N. $70 \mathrm{E}$.

Dendritic and cellular tufa (fig. 2, unit Qt). reportedly of algal origin (Morrison, 1964). drape parts of the granodiorite. Cavities in the tufa typically are filled with detrital biotite, hornblende, and lesser amounts of other detrital minerals making chemical analysis of the unit quite variable. The tufa is confined to the area below the 4,400-ft contour (approximate upper level of Pleistocene Lake Lahontan, Mnmison, 1964). Some of the authors of this report believe that the tufa (calcareous sinter) deposits along the southwest slopes of the study area are of thermal-spring origin, and others believe that they precipitated from chemically saturated lake water.

\section{Geochemical Studies}

Geochemical studies of the study area were conducted at two levels: a regional reconnaissance survey (Barringer Research Inc., 1982) with an average sample density of one sample per square mile, and a more detailed study (Day and others. 1986) of an area shown by the Barringer st udy to contain relatively high concentrations of arsenic.

In the Barringer study, 54 stream-sediment samples were collected from sites along the range front. Analytical resul ts of this survey show relatively high concentrations of arsenic, cadmium, copper, fluorine. strontium, uranium, and zinc. The distribution of these elements may reflect enrichment or depletion in older and younger parts of a pluton (Hildreth, 1981).

Twenty-nine sites were sampled (both streamsediment and rock samples) along a 4-mile zone in the southern part of the study area. Analyses of the nonmagnetic part of heavy-mineral concentrates in the stream-sediment samples show anomalous concentrations of lead, scandium, and thorium (Day and others, 1986). Sphene, which contains minor amounts of thorium, was identified in all but two samples and is the probable source of the thorium. The occurrence of anomalous lead and scandium, each at a single site. is not significant. Chemical analyses of rock samples show concentrations of antimony, arsenic, bismuth, cadmium, and silver that are greater than the normal range in fresh granodiorite from the 
area (Day and others, 1986). This suite of elements is characteristic of precious-metal deposits (Boyle. 1984).

\section{Geophysical Studies}

Concentrations of potassium and equivalent thorium and uranium were estimated for the study area by examining composite-color maps of gammaray spectrometric data (J.S. Duval, written commun., 1985). The data were obtained from radiometric profiles compiled by Geodata International, Inc. (1978). Based on criteria discussed by Duval (1983), the study area has moderate radioactivity with values of 1.5 to 2.5 percent potassium, 6 to $12 \mathrm{ppm}$ equivalent thorium, and 2.0 to $3.5 \mathrm{ppm}$ equivalent uranium. There is no indication of anomalous concentrations of radioelements.

In 1984, the U.S. Geological Survey established 47 gravity stations in and near the study area to compile a regional gravity map (D. Plouff, unpub. data). Although lacking coverage along the crest of the Selenite Range, the Bouguer gravity-anomaly map shows a gravity high over the range that exceeds 10 milliGals relative to the surrounding valleys. The thickness of Quaternary sediments east and west of the range are believed to be insufficient to entirely account for the magnitude of the gravity high. Prominent gravity gradients along the east and west flanks of the range suggest that block-faulting occurred along inferred major faults (fig. 2) that separate the crystalline core of the range from the surrounding, less dense basement rocks.

An aeromagnetic map of the region shows a distinct magnetic high located over the Selenite Range (U.S. Geological Survey, 1972). The shape of the anomaly closely conforms to topography; hence, it reflects moderate magnetization of the granodiorite. The aeromagnetic survey was flown at a constant barometric elevation of $9,000 \mathrm{ft}$ above sea level. Consequently, the level of magnetic intensity is about 100 nanoteslas lower along a flightline near Mount Limbo $(7.312 \mathrm{ft})$ than along a flightline near Kumiva Peak $(8,237 \mathrm{ft})$. The shape of the magnetic high is similar to that of the gravity high, but the magnetic gradient along the west flank of the range is more linear and extends farther south than the gravity gradient, and the magnetic gradient along the east flank is less pronounced. The small scale of the aeromagnetic map $(1: 250,000)$, the wide spacing of flightlines $(2 \mathrm{mi})$, and strong topographic effects limit interpretation to defining the margin of the granodiorite of Mount Limbo.

\section{MINERAL AND ENERGY RESOURCES}

Anomalous concentrations of arsenic, antimony. bismuth, cadmium, and silver, coupled with permissive host rock and the presence of faults and veins in an area in the southern part of the Mount Limbo Wilderness Study Area (fig. 2), indicate that the mineral resource potential for gold and silver at depth is moderate with a $C$ certainty level. See fig. 3 and appendix 1 for definitions of levels of mineral resource potential and certainty of assessment. No estimate of depth to or size of the body of mineralized rock can be made from the available data.

The rest of the study area has a low mineral resource potential (certainty level C) for gold and silver. Plutonic rock commonly is the host for baseand precious-metal deposits, but the lack of hydrothermal alteration and the sporadic. isolated distribution of the geochemical anomalies indicate that the probability of the occurrence of a vein or disseminated type of mineral deposit in this area is low.

Geothermal energy resource potential is low (certainty level C) throughout the study area. A known geothermal resource area four mi west of the study area in the San Emidio Desert (fig. 1, KGRA) has water temperatures as high as $95^{\circ} \mathrm{C}$ (Muffler, 1978), but there is no evidence that a hydrothermal system extends into the study area.

The predominant rock type in the study area is granodiorite, which is an unfavorable host for petroleum and natural gas accumulation.

\section{REFERENCES CITED}

Barringer Resources, Inc., 1982 , Geochemical and geostatistical evaluation of wilderness study areas, Winnemucca district, northwest Nevada, 5 v.: Golden, Colo. available from NTIS, U.S. Department of Commerce, Springfield, VA 22161, or call Information Center and Bookstore (202) 377-0365.

Crewdson, R.A., 1974, The geology and mineral deposits of part of the Selenite Range, Pershing County, Nevada: Golden, Colo., Colorado School of Mines, M.S. Thesis, $65 \mathrm{p}$.

Day, Gorden W., Turner, R.L., Conklin, Nancy N., and Briggs, Paul, 1986, Analytical results and sample location map of heavy-mineral concentrates and rock samples from the Mount Limbo Wilderness Study Area (NV 020-201), Pershing County, Nevada: U.S. Geological Survey Open-File Report 86-378 in press.

Duval, J.S., 1983, Composite color images of aerial gamma-ray spectrometric data: Geophysics, v. 48 , no. 6 , p. $722-735$.

Geodata International, Inc., 1978, Aerial radiometric and magnetic survey, Lovelock national topographic map, Nevada: U.S. Department of Energy Open-File Report GJBX-125 (78), v. 2, 69 p.

Hildreth, W., 1981, Gradients in silicic magma chambers: Implications for lithospheric magmatism: Journal of Geophysical Research, v. 86, no. B11, p. 10153-10192.

Johnson, M.G., 1977, Geology and mineral deposits of Pershing County, Nevada: Nevada Bureau of Mines and Geology Bulletin 89, 115 p.

Morrison, R.B., 1964, Lake Lahontan: Geology of southern Carson Desert, Nevada: U.S. Geological Survey Professional Paper 401, 156p.

Muffler, L.J.P., ed., 1978, Assessment of geothermal resources of the United States--1978: U.S. Geological Survey Circular 790, 163 p.

Rumsey, C.M., 1986, Mineral resources of the Mount 
Limbo Wilderness Study Area and vicinity, Pershing County, Nevada: U.S. Bureau of Mines Open-File Report 35-86, 11 p.

Smith, J.G., McKee, E.H., Tatlock, D.B., and Marvin, R.F., 1971, Mesozoic granitic rocks in northwestern Nevada--a link between the Sierra Nevada and Idaho Batholiths: Geological Society of America Bulletin, v. 82, p. 2933-2944.
U.S. Bureau of Land Management, 1983, Mount Limbo Wilderness Study Area, in Winnemucca Wilderness Technical Report, WNP T830094332, p. $131-146$.

U.S. Geological Survey, 1972, Aeromagnetic map of parts of the Lovelock, Reno, and Millet $1^{\circ}$ by $2^{\circ}$ quadrangles, Nevada: U.S. Geological Survey Open-file Report, 1 pl., scale 1:250,000. 
Table 1.- Descriptions of prospects and sinter or tufa sites in the Mt. Linbo Wilderness Study Area [Asterisk Indicates locations outside the study area]

\begin{tabular}{|c|c|c|c|c|}
\hline $\begin{array}{l}\text { Map } \\
\text { No. }\end{array}$ & Name & Summary & Workings and production & Sample and resource data \\
\hline 1 & $\begin{array}{l}\text { Pinto prospect } \\
\text { (silver-uranium) }\end{array}$ & $\begin{array}{l}\text { A 5-ft-thick limonite-stalned quartz } \\
\text { veln and float "occur" along a range- } \\
\text { front fault that parallels a contact } \\
\text { between granodiorite and volcanic } \\
\text { rocks. The fault strikes N. } 10^{\circ} \text { E., } \\
\text { dips } 65^{\circ} \mathrm{NW} ., \text { and can be traced for } \\
6 \mathrm{mf} \text {. }\end{array}$ & One prospect pit. & $\begin{array}{l}\text { Eight samples: one chip sample } \\
\text { collected across the quartz vein } \\
\text { contained } 3.532 \text { ppm silver; one grab } \\
\text { sample of quartz from the prospect } \\
\text { pit contained no gold or silver; one } \\
\text { of six other grab samples from along } \\
\text { the fault contained } 1.041 \text { ppm silver } \\
\text { and two each had } 0.97 \text { ppm } U_{3} 0_{8} \text {. }\end{array}$ \\
\hline 2 & $\begin{array}{l}\text { Unnamed prospect } \\
\text { (silver-uranium) }\end{array}$ & $\begin{array}{l}\text { A 6-ft-thick, fron-oxide-stalned } \\
\text { smoky quartz veln with an attitude of } \\
\mathrm{N} .45^{\circ} \mathrm{W}, 35^{\circ} \mathrm{NE} \text {. is exposed for } \\
7 \mathrm{ft} \text { in granodiorite. }\end{array}$ & One prospect pit. & $\begin{array}{l}\text { One chip sample contained } 9.19 \mathrm{ppr} \\
\text { silver and } 4.0 \mathrm{ppm} \mathrm{U}_{3} \mathrm{O}_{8} .\end{array}$ \\
\hline 3 & $\begin{array}{l}\text { Unnamed prospect } \\
\text { (uranium) }\end{array}$ & $\begin{array}{l}\text { Iron-oxide-stained contact between } \\
\text { granodiorite and rhyolite trends } \\
\text { generally easterly. }\end{array}$ & $\begin{array}{l}\text { Two } 150-\text { by } 2-f t \text {-deep } \\
\text { trenches, and a prospect } \\
\text { p1t. }\end{array}$ & $\begin{array}{l}\text { Three chip and two grab samples: chip } \\
\text { samples of granodiorite contained } 2.8 \\
\text { to } 5.1 \text { ppm } \mathrm{U}_{3} \mathrm{O}_{8} ; \text { a grab sample of } \\
\text { concentrated black sand had } 544 \mathrm{ppm} \\
\mathrm{U}_{3} \mathrm{O}_{8} \text {; and a grab sample from a dump } \\
\text { contained } 3.5 \mathrm{ppm} \mathrm{U}_{3} \mathrm{O}_{8} \text {. }\end{array}$ \\
\hline 4 & $\begin{array}{l}\text { Sinter or tufa site } \\
\text { (uranium) }\end{array}$ & $\begin{array}{l}\text { About } 80 \text { percent of the granodiorite } \\
\text { in a } 500-\text { by } 2,200-\mathrm{ft} \text { area is coated } \\
\text { with calcareous sinter or tufa that } \\
\text { is } 0.5 \text { to } 4 \mathrm{ft} \text { thick. }\end{array}$ & None. & $\begin{array}{l}\text { Three ch1p samples and one grab } \\
\text { sample of sinter or tufa contained } \\
\text { between } 1.8 \text { and } 2.8 \text { ppm } \mathrm{U}_{3} 0_{8} \text {. }\end{array}$ \\
\hline 5* & $\begin{array}{l}\text { Unnamed prospect } \\
\text { (uranium) }\end{array}$ & $\begin{array}{l}\text { Altered rhyolite tuff and } \\
\text { granodiorite "occur" along a contact } \\
\text { that strikes } \mathrm{N} .85^{\circ} \text { E. and dips } \\
45^{\circ} \mathrm{N} \text {. }\end{array}$ & A $90-\mathrm{ft}$ trench & $\begin{array}{l}\text { Five chip samples taken along the } \\
\text { contact contained from } 2.8 \text { to } 7.0 \text { ppm } \\
\mathrm{U}_{3} 0_{8} \text {. }\end{array}$ \\
\hline $6 *$ & $\begin{array}{l}\text { Unnamed prospect } \\
\text { (silver-uranium- } \\
\text { gold) }\end{array}$ & $\begin{array}{l}\text { A } 0.5-f t-t h 1 c k, \text { fron-oxide-stained } \\
\text { quartz vein "occurs" in altered } \\
\text { granodiorite }\end{array}$ & Two $30-f t$ trenches & $\begin{array}{l}\text { Three chip samples contained } 1.047 \text { to } \\
1.209 \text { ppn silver and } 2.7 \text { to } 4.0 \mathrm{ppm} \\
\mathrm{O}_{3} \mathrm{O}_{8} \text {; one had } 0.04 \mathrm{ppm} \text { gold. }\end{array}$ \\
\hline 7 & $\begin{array}{l}\text { Sinter or tufa site } \\
\text { (silver-uraniua) }\end{array}$ & $\begin{array}{l}\text { About } 60 \text { percent of a } 170-\text { by } 85-\mathrm{ft} \\
\text { area of granodiorite } 1 \mathrm{~s} \text { coated with } \\
\text { calcium carbonate } 1 \mathrm{ft} \text { thick. }\end{array}$ & None. & $\begin{array}{l}\text { Four chip samples contained from } 1.00 \\
\text { to } 1.142 \text { ppis silver; three conta1ned } \\
3.4 \text { to } 3.7 \mathrm{ppm} \mathrm{U}_{3} 0_{8} \text {. }\end{array}$ \\
\hline 8 & $\begin{array}{l}\text { Sinter or tufa site } \\
\text { (gold-uranium) }\end{array}$ & $\begin{array}{l}\text { Calcareous sinter or tufa at a former } \\
\text { thermal spring coats about } 25 \text { percent } \\
\text { of underlying granodiorite to a } \\
\text { thickness of } 1.5 \mathrm{ft}, 50 \text { to } 300 \mathrm{ft} \\
\text { from the spring. }\end{array}$ & None. & $\begin{array}{l}\text { Four chip samples contained from } 1.5 \\
\text { to } 6.4 \mathrm{ppm} \mathrm{U}_{3} 0_{8} \text {; one had } 0.008 \mathrm{ppm} \\
\text { gold. }\end{array}$ \\
\hline $9 *$ & $\begin{array}{l}\text { Unnamed prospect } \\
\text { (silver-lead- } \\
\text { uranium) }\end{array}$ & $\begin{array}{l}\text { A } 1,600-f t \text {-wide zone of leached and } \\
\text { 1 ron-oxide-stained quartz veins } \\
\text { trends northeasterly in granodiorite. }\end{array}$ & $\begin{array}{l}\text { About an acre of the ridge } \\
\text { top was bulldozed. }\end{array}$ & 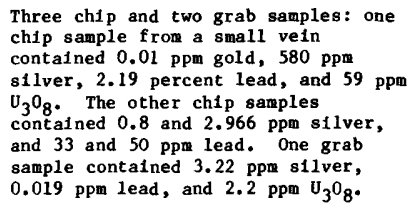 \\
\hline $10^{\star}$ & $\begin{array}{l}\text { Sinter or tufa site } \\
\text { (silver-uranium- } \\
\text { gold) }\end{array}$ & $\begin{array}{l}\text { Calcareous sinter or tufa, at least } \\
0.5 \mathrm{ft} \text { thick, overlies granodiorite } \\
520 \mathrm{ft} \text { from former thermal springs. }\end{array}$ & None. & $\begin{array}{l}\text { Three chip samples contained from } \\
0.989 \text { to } 1.191 \text { ppm silver and } 3.4 \text { to } \\
5.1 \text { ppm } \mathrm{U}_{3} 0_{8} \text {; two had } 0.024 \text { and } 0.058 \\
\text { ppm gold. }\end{array}$ \\
\hline $11 *$ & $\begin{array}{l}\text { Sinter or tufa site } \\
\text { (silver-gold) }\end{array}$ & $\begin{array}{l}\text { Calcium carbonate sinter or tufa of } \\
\text { undetermined thickness coats } \\
\text { granodiorite over a } 50-\mathrm{ft} \text { diameter } \\
\text { area. }\end{array}$ & None. & $\begin{array}{l}\text { Three chip samples contalned from } \\
1.042 \text { to } 1.217 \mathrm{ppm} \text { s1lver; two had } \\
0.018 \text { and } 0.124 \mathrm{ppm} \text { gold. }\end{array}$ \\
\hline $12 *$ & $\begin{array}{l}\text { Sinter or tufa site } \\
\text { (silver-uranium) }\end{array}$ & $\begin{array}{l}\text { Calcium carbonate sinter or tufa } 0.1 \\
\text { to more than } 10-f t-t \text { thick coats about } \\
80 \text { percent of the granodiorite within } \\
\text { a l-acre area that lncludes former } \\
\text { thermal springs. }\end{array}$ & None & $\begin{array}{l}\text { Four chip samples contained from } 2.4 \\
\text { to } 3.8 \mathrm{ppm} \mathrm{U}_{30}{ }_{8} \text {; three had } 0.997 \text { to } \\
1.106 \mathrm{ppm} \text { silver. }\end{array}$ \\
\hline $13 *$ & $\begin{array}{l}\text { Unnamed prospect } \\
\text { (silver-uranium) }\end{array}$ & $\begin{array}{l}\text { Two 1-ft-thick aplite dikes enclose } \\
0.3-\mathrm{ft}-\mathrm{th} \text { ck veins of } 1 \text { ron-oxide- } \\
\text { stained quartz. The dikes are } 5 \mathrm{ft} \\
\text { apart, exposed for } 50 \mathrm{ft} \text {, trend } \\
\text { northward, and dip } 10^{\circ} \text { eastward in } \\
\text { granodiorite. }\end{array}$ & None & $\begin{array}{l}\text { Two chip samples contained } 1.175 \text { and } \\
1.336 \mathrm{ppm} \text { silver, and } 5.9 \text { and } 6.5 \mathrm{ppm} \\
\mathrm{U}_{3} 0_{8} \text {. }\end{array}$ \\
\hline $14 *$ & $\begin{array}{l}\text { L1 mbo group } \\
\text { (uranium-silver- } \\
\text { gold) }\end{array}$ & $\begin{array}{l}\text { A } 4 \text {-ft-thick, tron-oxide-stained } \\
\text { quartz vein which strikes } \mathrm{N} \text {. } 30^{\circ} \mathrm{w} \text {. } \\
\text { and dips } 60^{\circ} \mathrm{NE}, \text { is exposed for } 200 \\
\text { ft in granodiorite. }\end{array}$ & One $18-f t$ adit. & $\begin{array}{l}\text { Ten samples of the quartz vein } \\
\text { contained from } 3.2 \text { to } 153 \text { ppm } \mathrm{U}_{3} \mathrm{O}_{8} \text {. } \\
\text { Two samples had } 0.007 \text { and } 0.013 \mathrm{ppm} \\
\text { gold, and nine contained from } 1.149 \\
\text { to } 5.023 \text { ppo silver. }\end{array}$ \\
\hline $15 *$ & $\begin{array}{l}\text { Sinter or tufa site } \\
\text { (uranium) }\end{array}$ & $\begin{array}{l}\text { Calcium carbonate sinter or tufa } 1 \text { to } \\
5 \mathrm{ft} \text { thick near a former thermal } \\
\text { spring coats basalt on a mound that } \\
\text { is } 100 \mathrm{ft} \text { wide and } 50 \mathrm{ft} \text { high. }\end{array}$ & None & $\begin{array}{l}\text { Two chip samples contained } 1.3 \text { and } \\
4.1 \mathrm{ppm} \mathrm{U}_{3} \mathrm{O}_{8} \text {. }\end{array}$ \\
\hline $16 *$ & $\begin{array}{l}\text { Unnated prospect } \\
\text { (uraniun) }\end{array}$ & $\begin{array}{l}\text { Three 2-ft-thick, aplite dikes within } \\
400 \text { lateral feet strike between due } \\
\text { north and } \mathrm{N} .30^{\circ} \mathrm{W} \text {. and dip } \\
\text { vertically in altered granodiorite. }\end{array}$ & $\begin{array}{l}\text { Minor trenches and topsoil } \\
\text { bul1dozed from a } 40 \text { by } 100 \\
\text { ft area. }\end{array}$ & $\begin{array}{l}\text { Five samples: four had from } 1.8 \text { to } \\
7.5 \mathrm{ppm} \mathrm{U}_{3} \mathrm{O}_{8} \text {. }\end{array}$ \\
\hline
\end{tabular}




\section{APPENDIX 1. Definition of levels of mineral resource potential and certainty of assessment}

Mineral resource potential is defined as the likelihood of the presence of mineral resources in a defined area; it is not a measure of the amount of resources or their profitability.

Mineral resources are concentrations of naturally occurring solid, liquid, or gaseous materials in such form and amount that economic extraction of a commodity from the concentration is currently or potentially feasible.

Low mineral resource potential is assigned to areas where geologic, geochemical, and geophysical characteristics indicate a geologic environment where the existence of resources is unlikely. This level of potential embraces areas of dispersed mineralized rock as well as areas having few or no indications of mineralization. Assignment of low potential requires specific positive knowledge; it is not used as a catchall for areas where adequate data are lacking.

Moderate mineral resource potential is assigned to areas where geologic, geochemical, and geophysical characteristics indicate a geologic environment favorable for resource occurrence, where interpretations of data indicate a reasonable chance for resource accumulation, and where an application of genetic and (or) occurrence models indicates favorable ground.

High mineral resource potential is assigned to areas where geologic, geochemical, and geophysical characteristics indicate a geologic environment favorable for resources, where interpretations of data indicate a high likelihood for resource accumulation, where data support occurrence and (or) genetic models indicating presence of resources, and where evidence indicates that mineral concentration has taken place. Assignment of high resource potential requires positive knowledge that resource-forming processes have been active in at least part of the area; it does not require that occurrences or deposits be identified.

Unknown mineral resource potential is assigned to areas where the level of knowledge is so inadequate that classification of the area as high, moderate, or low would be misleading. The phrase "no mineral resource potential" applies only to a specific resource type in a well-defined area. This phrase is not used if there is the slightest possibility of resource occurrence; it is not appropriate as the surnmary rating for any area.

Expression of the certainty of the mineral resource assessment incorporates a consideration of (1) the adequacy of the geologic, geochemical, geophysical, and resource data base available at the time of the assessment, (2) the adequacy of the occurrence or the genetic model used as the basis for a specific evaluation, and (3) an evaluation of the likelihood that the expected mineral endowment of the area is, or could be, economically extractable.

Levels of certainty of assessment are denoted oy letters, A-D (fig. 3).

A. The available data are not adequate to determine the level of mineral resource potential. Level $A$ is used with an assignment of unknown mineral resource potential.

B. The available data are adequate to suggest the geologic environment and the level of mineral resource potential, but either evidence is insufficient to establish precisely the likelihood of resource occurrence, or occurrence and (or) genetic models are not known well enough for predictive resource assessinent.

C. The available data give a good indication of the geologic environment and the level of mineral resource potential, but additional evidence is needed to establish precisely the likelihood of resource occurrence, the activity of resource-forming processes, or available occurrence and (or) genetic models are minimal for predictive applications.

D. The available data clearly define the geologic environment and the level of mineral resource potential, and indicate the activity of resourceforming processes. Key evidence to interpret the presence or absence of specified types of resources is available, and occurrence and (or) genetic models are adequate for predictive resource assessment.

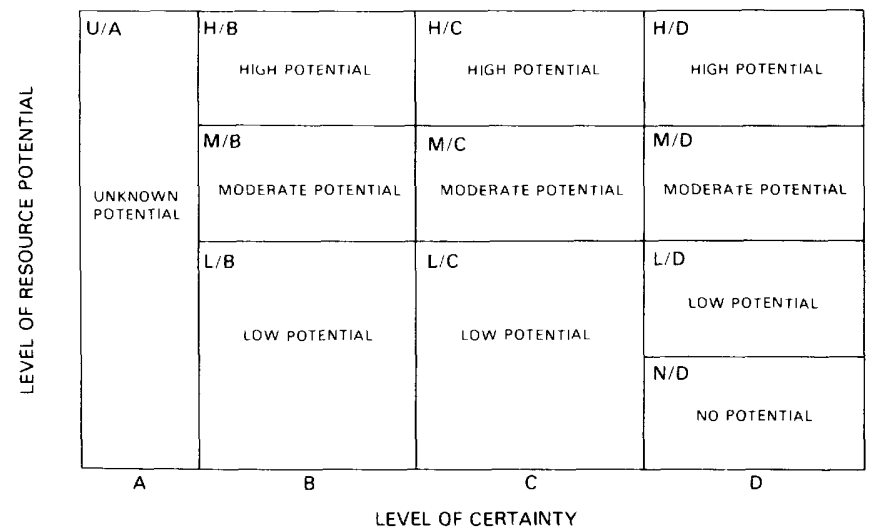

Figure 3. Major ele ments of mineral resource potential/certainty classification. 
GEOLOGIC TIME CHART

Terms and boundary ages used by the U.S. Geological Survey in this report

\begin{tabular}{|c|c|c|c|c|c|}
\hline EON & ERA & \multicolumn{2}{|c|}{ PERIOD } & EPOCH & $\begin{array}{l}\text { AGE ESTIMATES } \\
\text { OF BOUNDARIES } \\
\text { (in Ma) }\end{array}$ \\
\hline \multirow{17}{*}{ Phanerozoic } & \multirow{7}{*}{ Cenozoic } & \multirow{2}{*}{\multicolumn{2}{|c|}{ Quaternary }} & Holocene & 0.010 \\
\hline & & & & Pleistocene & \\
\hline & & \multirow{5}{*}{ Tertiary } & \multirow{2}{*}{$\begin{array}{l}\text { Neogene } \\
\text { Subperiod }\end{array}$} & Pliocene & 5 \\
\hline & & & & Miocene & \\
\hline & & & \multirow{3}{*}{$\begin{array}{l}\text { Paleogene } \\
\text { Subperiod }\end{array}$} & Oligocene & \\
\hline & & & & Eocene & 30 \\
\hline & & & & Paleocene & 0 \\
\hline & \multirow{3}{*}{ Mesozoic } & \multicolumn{2}{|c|}{ Cretaceous } & $\begin{array}{l}\text { Late } \\
\text { Early }\end{array}$ & $\begin{array}{r}-90 \\
-96\end{array}$ \\
\hline & & \multicolumn{2}{|c|}{ Jurassıc } & $\begin{array}{l}\text { Late } \\
\text { Middle } \\
\text { Early }\end{array}$ & -138 \\
\hline & & \multicolumn{2}{|c|}{ Triassic } & $\begin{array}{l}\text { Late } \\
\text { Middle } \\
\text { Early }\end{array}$ & 200 \\
\hline & \multirow{7}{*}{ Paleozoic } & \multicolumn{2}{|c|}{ Permian } & $\begin{array}{l}\text { Late } \\
\text { Early }\end{array}$ & 270 \\
\hline & & \multirow{2}{*}{$\begin{array}{c}\text { Carboniferous } \\
\text { Periods }\end{array}$} & Pennsylvanian & $\begin{array}{l}\text { Late } \\
\text { Middle } \\
\text { Early }\end{array}$ & 200 \\
\hline & & & Mississippian & $\begin{array}{l}\text { Late } \\
\text { Early }\end{array}$ & 260 \\
\hline & & \multicolumn{2}{|c|}{ Devonian } & $\begin{array}{l}\text { Late } \\
\text { Middle } \\
\text { Early }\end{array}$ & 0 \\
\hline & & \multicolumn{2}{|c|}{ Silurian } & $\begin{array}{c}\text { Late } \\
\text { Middle } \\
\text { Early }\end{array}$ & 410 \\
\hline & & \multicolumn{2}{|c|}{ Ordovician } & $\begin{array}{l}\text { Late } \\
\text { Middle } \\
\text { Early }\end{array}$ & \\
\hline & & \multicolumn{2}{|c|}{ Cambrian } & $\begin{array}{l}\text { Late } \\
\text { Middle } \\
\text { Early }\end{array}$ & 500 \\
\hline \multirow{3}{*}{ Proterozoic } & Late ProterozoIc & & & & 00 \\
\hline & Middle Proterozoic & & & & \\
\hline & Early Proterozoic & & & & 1000 \\
\hline \multirow{3}{*}{ Archean } & Late Archean & & & & 2500 \\
\hline & Middle Archean & & & & 3000 \\
\hline & Early Archean & & & & 40 \\
\hline
\end{tabular}

'Rocks older than $570 \mathrm{Ma}$ also called Precambrian, a time term without specific rank.

${ }^{2}$ Informal time term without specific rank. 


$$
\text { . }
$$



